\begin{tabular}{|c|c|c|}
\hline \multirow{3}{*}{ 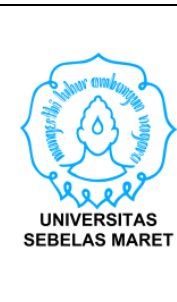 } & DWIJA CENDEKIA: Jurnal Riset Pedagogik 4 (2) (2020) 175-185 & $=$ \\
\hline & DM & 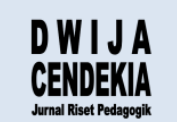 \\
\hline & https://jurnal.uns.ac.id/jdc & (9) ws \\
\hline
\end{tabular}

\title{
Peningkatan Keterampilan Menulis Karya IImiah Melalui Model Pembelajaran Kooperatif Tipe Group Investigation
}

\author{
Maria Ulfa \\ STKIP Kusumanegara \\ mariaulfa@stkipkusumanegara.ac.id
}

\section{Sejarah Artikel}

diterima 25 September 2020 disetujui 20 November 2020 diterbitkan 1 Desember 2020

\begin{abstract}
The aims of this study was to improve scientific papers writing skills through by using cooperative learning model type of the group investigation. The Research subjects used were the first semester students of PGSD department, STKIP Kusuma Negara, totaling 30 students. The research time is September to December or the odd semester academic year of the 2018-2019. The research method used in this research is classroom action research. The research model used was the design of Kemmis and Taggart with 3 cycles. This research was conducted in four phases, namely: planning, action, observing, and reflecting. The data in this study were obtained from tests of writing scientific papers, observation, interviews, field notes, and documentation. The results showed that the cooperative learning model type of the group investigation could improve the writing skills of semester I students. Based on the findings, it was suggested that Indonesian lecturers apply the cooperative learning model type of the group investigation for learning writing skills.
\end{abstract}

Keywords: students writing scientific works and investigation group type cooperarive learning model

\begin{abstract}
Abstrak
Tujuan penelitian ini adalah untuk meningkatkan keterampilan menulis karya ilmiah melalui model pembelarajan kooperatif tipe group investigation. Subjek penelitian ini adalah mahasiswa semester I prodi PGSD, STKIP Kusuma Negara yang berjumlah 30 mahasiswa. Waktu penelitian adalah bulan September sampai dengan Desember atau pada semester ganjil tahun ajaran 20182019. Metode penelitian yang digunakan pada penelitian ini adalah classroom action research atau Penelitian Tindakan Kelas (PTK). Model penelitian yang digunakan adalah desain Kemmis dan Taggart dengan 3 siklus. Penelitian ini dilakukan melalui empat fase, yakni: perencanaan, pelaksanaan tindakan, pengamatan, dan refleksi. Data dalam penelitian ini diperoleh dari tes menulis karya ilmiah, obeservasi, wawancara, catatan lapangan dan dokumentasi. Hasil penelitian menunjukan bahwa melalui model pembelajaran kooperatif tipe group investigation dapat meningkatkan keterampilan menulis karya ilmiah mahasiswa Semester I Prodi PGSD, STKIP Kusuma Negara. Berdasarkan hasil temuan, disarankan kepada dosen mata kuliah Bahasa Indonesia dapat menerapkan model pembelajaran kooperatif tipe group investigation untuk pembelajaran keterampilan menulis.

Kata Kunci: keterampilan menulis karya ilmiah, model pembelajaran, kooperatif tipe group investigation
\end{abstract}




\section{PENDAHULUAN}

Manusia adalah salah satu makhluk hidup ciptaan Tuhan. Di antara makhluk ciptaan Tuhan lainnya, manusialah yang paling tinggi derajatnya. Manusia memiliki derajat yang paling tinggi di antara makhluk ciptaan Tuhan lainnya karena hanya manusia yang dibekali kemampuan untuk dapat berpikir.

Dengan kemampuan untuk berpikir, manusia dapat menuangkan segala ide atau gagasan yang dimiliki untuk disampaikan kepada khalayak umum. Dan atas dasar itulah manusia disebut makhluk sosial.

Untuk dapat menjadi makhluk sosial seutuhnya manusia harus melakukan interaksi dan berkomunikasi dengan sesama manusia lain. Untuk dapat berinteraksi dan berkomunikasi manusia membutuhkan sebuah alat, yakni bahasa.

Bahasa adalah suatu sistem simbol lisan yang arbitrer yang dipakai oleh anggota suatu masyarakat bahasa untuk berkomunikasi dan berinteraksi antar sesamanya, berlandaskan pada budaya yang mereka miliki bersama (Dardjowodjojo, 2018: 16).

Bahasa mempunyai peran utama dalam terciptanya masyarakat yang santun dan beradab. Seorang pemakai bahasa dapat dikatakan santun atau tidak ditentukan oleh sikap dalam berbahasanya, meliputi intonasi dan makna yang diucapkan melalui lisan atau diksi dan makna kata yang dituliskan melalui kata-kata.

Manusia dapat berpikir karena memiliki kemampuan dalam berbahasa (Chaer, 2015: 58). Jika manusia ingin mengungkapkan berbagai pemikirannya dengan baik dan tepat, maka manusia haruslah menguasai bahasa dengan baik juga Kemampuan manusia dalam berpikir dan berbahasa dapat dilatih dengan melakukan aktivitas keterampilan untuk memupuk diri untuk terampil.

Seorang dikatakan mempunyai kemampuan apabila telah melalui dan menyelesaikan sebuah proses. Proses yang harus dilalui dalam berbahasa ialah empat aspek keterampilan berbahasa. Keempat aspek ini bukan hanya mendukung melainkan dalam konteks ruang lingkup kehidupan pun saling berhubungan erat. Keempat keterampilan tersebut adalah keterampilan menyimak, berbicara, membaca, dan menulis (Tarigan, 2008: 1).

Dari keempat ketrampilan berbahasa tersebut di atas terdapat satu ketrampilan yang dianggap paling kompleks, yakni keterampilan menulis. Keterampilan menulis merupakan keterampilan yang tidak dapat diperoleh secara autodidak. Keterampilan menulis diperoleh melalui proses pembelajaran. Menulis merupakan kegiatan yang sifatnya berkelanjutan sehingga pembelajarannya pun perlu dilakukan secara berkesinambungan dan terusmenerus. Diawali dengan kemampuan menulis permulaan pada sekolah dasar dan dilanjutkan dengan kemampuan menulis lanjutan. Oleh karena itu, pembelajaran menulis di setiap jenjang perlu mendapat perhatian yang optimal sehingga dapat memenuhi target kemampuan menulis yang diharapkan. Bukan hanya menjiplak, menyalin, namun juga mampu menciptakaan tulisan yang baik dan berkualitas.

Dalam Undang-Undang Nomor 20 Tahun 2003 pasal 25 ayat 1 disebutkan Perguruan tinggi 
menetapkan persyaratan kelulusan untuk mendapatkan gelar akademik, profesi, atau vokasi. Sejalan dengan berlakunya UU tersebut, STKIP Kusuma Negara mewajibkan penulisan karya ilmiah, yakni skripsi sebagai salah satu persyaratan kelulusan mahasiswa memperoleh gelar sarjana.

Mengapa harus membuat karya tulis ilmiah? Sebab karya tulis ilmiah merupakan salah satu acuan terhadap kemajuan ilmu pengetahuan dan teknologi suatu bangsa. Kemajuan suatu bangsa dan negara dapat diukur dari maju atau tidaknya komunikasi tulis bangsa tersebut. Maju atau tidaknya komunikasi tulis dapat dilihat dan diukur dari kualitas dan kuantitas hasil percetakan yang terdapat di negara tersebut (Tarigan, 2008: 20).

Karya tulis ilmiah yang dibuat oleh mahasiswa sebagai salah satu persyaratan memperoleh gelar akademik tentunya dapat dipublikasikan pada prosiding, jurnal nasional maupun internasional. Ini merupakan salah satu ukuran penting untuk melihat kualitas penelitian di sebuah negara.

Setiap mahasiswa Prodi PGSD, STKIP Kusuma Negera yang akan lulus menjadi sarjana haruslah menyelesaikan tugas akhir, yakni menulis karya ilmiah berupa skripsi. Untuk dapat menulis skripsi mahasiswa dibekali pengetahuan dan pemahaman tentang sistematika penulisan karya ilmiah dari semester I, melalui mata kuliah bahasa Indonesia.

Mata kuliah bahasa Indonesia adalah mata kuliah wajib yang harus diikuti setiap mahasiswa semester I Prodi PGSD, STKIP Kusuma Negara. Mahasiswa wajib mengambil mata kuliah dasar umum Bahasa Indonesia, hal ini sesuai dengan Undang-Undang Nomor 12 Tahun 2002 pasal 35 ayat 3 tentang Perguruan Tinggi, dimana mata kuliah bahasa Indonesia adalah salah satu mata kuliah umum yang wajib diajarkan di perguruan tinggi pada level diploma dan sarjana. Pada mata kuliah bahasa Indonesia salah satu capaian mata kuliahnya adalah mahasiswa diharapkan terampil membuat karya tulis ilmiah (proposal/artikel ilmiah) dengan pemakaian bahasa Indonesia yang baik (jelas/lugas, objektif, rasional/logis, dan benar (sesuai dengan kaidah PUEBI dan notasi ilmiah).

Pengetahuan dan pemahaman bahasa Indonesia yang dibekali untuk mahasiswa pada semester I tersebut menjadi modal awal mahasiswa dalam membuat tugas-tugas di mata kuliah lain dan sebagai bekal dalam membat karya ilmiah sebagai persyaratan untuk lulus menjadi seorang sarjana. Pada semester I mahasiswa Prodi PGSD sudah dihadapkan dengan berbagai macam tugas yang menuntut keterampilan menulis khususnya menulis karya ilmiah.

Pengalaman penulis sebagai dosen mata kuliah Bahasa Indonesia mengajarkan materi penulisan karya ilmiah di Prodi PGSD, STKIP Kusuma Negara Semester I yang menuntut mahasiswa untuk menulis karya ilmiah masih sangatlah rendah. Peneliti sebagai dosen menerapkan KKM 75, dan hanya $16,7 \%$ mahasiswa yang baru mampu mendapatkan nilai di atas KKM.

Hasil pengamatan peneliti terhadap rendahnya keterampilan mahasiswa semester I Prodi PGSD, STKIP Kusuma Negara hanya melakukan trik salin tempel (copy paste) dari google dalam menyelesaikan karya ilmiah yang diminta. Karya tulis ilmiah mahasiswa yang dihasilkan tidak menunjukan 
keorisinalitasn, mahasiswa juga tidak mampu menulis dengan menggunakan sistematika penulisan karya ilmiah (Pendahuluan, Pembahasan, dan Penutup), kebahasan (PUEBI, diksi, dan kalimat efektif), dan notasi penulisan ilmiah.

Berdasarkan pengalaman dan pengamatan tersebut, penulis selaku dosen mata kuliah bahasa Indonesia perlu mengkaji terkait sumber permasalahan rendahnya keterampilan menulis karya ilmiah mahasiswa semester I prodi PGSD, STKIP Kusuma Negara Perbaikan teknik mengajar agar permasalahan belajar yang ada di kelas tersebut bisa dipecahkan. Penulis memilih untuk menggunakan strategi belajar sebagai alternatif pemecahan masalah yang terjadi. Strategi yang dapat diterapkan dalam meningkatkan keterampilan menulis karya ilmiah adalah dengan menggunakan Model Pembelajaran Kooperatif Tipe Group Investigation.

Model pembelajaran kooperatif merupakan model pembelajaran dengan situasi pengelompokan mahasiswa yang dilakukan secara acak, sehingga kemampuan kognitif mahasiswa beragam (Afianti, Sulastri, dan Alimin, 2017: 44). Model pembelajaran kooperatif ini mengedepankan model pembelajaran diskusi kelompok sehingga semua mahasiswa yang tergabung dalam beberapa kelompok memiliki keharusan untuk mengungkapkan pendapatnya (Amelia dan Eva, 2014: 19). Model pembelajaran kooperatif dipilih oleh karena dirasa bahwa keterampilan menulis karya ilmiah mahasiswa PGSD masih sangatlah rendah. Diharapkan dengan bekerja secara berkelompok sesuai dengan karakteristik model pembelajaran kooperatif dapat membantu mahasiswa yang mengalami kesulitan dalam mengembangkan tulisan pada karya ilmiahnya. Dibentuknya kelompok-kelompok mahasiswa dapat menjadi sarana mahasiswa untuk berdiskusi tentang penulisan karya ilmiah bukan mengambil jalan pintas copy-paste dari google.

Model Pembelajaran Kooperatif Tipe Group Investigation adalah model yang dapat mengembangkan keterampilan berpikir dalam kelompokkelompok kecil yang memiliki kemampuan heterogen. Sebagai salah satu model pembelajaran kooperatif, group investigation merupakan pembelajaran yang kompleks. Group investigation mempunyai kelebihan diantaranya memberikan kesempatan berkolaborasi dengan teman sebaya dalam bentuk diskusi kelompok untuk memecahkan suatu masalah (Rusman, 2013: 201).

Ada enam langkah pembelajaran menggunakan model group investigation. Keenam langkah tersebut adalah sebagai berikut: 1) memilih topik, 2) perencanaan kooperatif, 3) implementasi, 4) analisis dan sintesis, 5) presentasi hasil final, and 6) evaluasi (Sharan dalam Suprapti, 2018: 22).

Karya tulis ilmiah merupakan gabungan narasi, deskripsi, dan eksposisi yang penulisannya didasarkan pada suatu penalaran atau logika tertentu, didukung bukti (evidence), dan disertai dengan argumen. Penalaran atau logika berhubungan dengan keabsahan penarikan kesimpulan, sedangkan argumen berhubungan dengan kebenaran premis yang digunakan sebagai dasar penarikan kesimpulan. Tulisan argumentasi bertujuan untuk mengubah sikap dan pendapat orang lain dengan menggunakan prinsipprinsip logika sebagai alat bantu utama (Sakaran, 2013: 12). 
Dalam menulis karya ilmiah sebuah tulisan haruslah memenuhi beberapa karakteristik. Adapun karakteristik yang dimaksud meliputi: 1) logis, 2) konseptual-teoritis, 3) kritisanalitis, 4) obyektif, 5) empiris, dan 6) sistematis (Davis and Cosenza, 1993: 45).

Karya tulis ilmiah yang akan dibuat mahasiswa dalam penelitian ini adalah karya tulis ilmiah dalam bentuk yang sederhana dimana menggunakan pendekatan kualitatif dengan jenis studi kepustakaan. Mahasiswa harus menjunjung keorisinalitasan tulisan mereka dengan menerapkan notasi penulisan ilmiah yang diterapkan oleh STKIP Kusuma Negara, yakni mencantumkan catatan kaki dalam setiap kutipan yang ditulis dalam karya ilmiah. Dengan mengharuskan menuliskan catatan kaki pada kutipan yang sudah ditulis diharapkan mampu memupuk rasa tanggung jawab dan anti plagiatisme mahasiswa.

Pedoman penulisan karya ilmiah disusun dengan menggunakan sistematika penulisan sebagai berikut: Bab I Pendahuluan, berisi tentang latar belakang masalah, identifikasi masalah, dan tujuan penulisan karya ilmiah. Bab II Pembahasan, uraian dan analisis dari topik yang dikembangkan di identifikasi masalah. Bab III Penutup, berisi tentang kesimpulan dan saran.

Berdasarkan uraian di atas, maka rumusan penelitian ini adalah bagaimana peningkatan keterampilan menulis karya ilmiah melalui model pembelajaran kooperatif tipe group investigation pada mahasiswa Program Studi PGSD STKIP Kusuma Negara tahun ajaran 2019-2020

\section{METODE PENELITIAN}

Penelitian ini menggunakan metode Penelitian Tindakan Kelas (PTK). Model PTK yang digunakan adalah Model Kemmis dan Taggart (1993) dengan menggunakan 3 siklus. Setiap siklus terdiri dari empat tahapan yaitu perencanaan (planning), tindakan (acting), observasi (observing), dan refleksi (reflecting) (Tampubolon, 2014: 154). Adapun subjek penelitian ini adalah 30 mahasiswa semester I
Prodi PGSD STKIP Kusuma Negara tahun akademik 2018-2019.

Teknik pengumpulan data yang dilakaukan dalam penelitian ini adalah dengan menggunakan tes menulis karya ilmiah, obeservasi, wawancara, catatan lapangan, dan dokumentasi. Adapaun rubrik penilaian dalam tes menulis karya ilmiah yang diguanakan adalah sebagai berikut:

\begin{tabular}{|c|c|c|}
\hline No. & Aspek penilaian & Bobot penilaian \\
\hline 1. & Orisinalitas & 20 \\
\hline 2. & Pengembangan topik & 20 \\
\hline 3. & Kesesuaian sistematika penulisan & 20 \\
\hline 4. & PUEBI & 20 \\
\hline \multirow[t]{2}{*}{5.} & Notasi penulisan ilmiah & 20 \\
\hline & Jumlah & 100 \\
\hline
\end{tabular}


Analisis data yang dipakai dalam penelitian ini adalah model Milles dan Huberman. Model Milles dan Huberman adalah model analisis data berlangsung atau mengalir (flow model analysis). Dalam model analisis data ini, ada empat aktivitas yang dilakukan, yaitu: pengumpulan data, reduksi data, display data, dan verifikasi atau menarik kesimpulan (Mukhtar, 2013: 136). Kriteria keberhasilan dalam penelitian ini adalah jika nilai mahasiswa dalam membuat karya ilmiah mencapai minimal $80 \%$ atau mahasiswa dari kriteria ketuntasan minimum, yakni 75 .

\section{HASIL DAN PEMBAHASAN}

Penelitian tindakan kelas ini dilakukan pada mahasiswa semester I prodi PGSD, STKIP Kusuma Negara yang berjumlah 30 mahasiswa dimana peneliti berperan juga sebagai dosen mata kuliah Bahasa Indonesia di kelas tersebut. Peneliti jugalah yang bertindak sebagai perencana, pelaksana dan pengajar di kelas tersebut. Berikut ini adalah data yang diperoleh dari hasil penelitian:

Tabel 1.

\section{Rekapitulasi Nilai Tes Menulis Karya IImiah}

\begin{tabular}{lccc}
\hline & $\begin{array}{c}\text { Rata-Rata Nilai } \\
\text { Menulis Karya } \\
\text { IImiah }\end{array}$ & $\begin{array}{c}\text { Presentasi } \\
\text { Mahasiswa } \\
\text { KKM }\end{array}$ & $\begin{array}{c}\text { Presentasi } \\
\text { Mahasiswa } \geq \\
\text { KKM }\end{array}$ \\
\hline Pra Tindakan & 58,5 & $80 \%$ & $20 \%$ \\
Siklus I & 63,5 & $70 \%$ & $30 \%$ \\
Sikslus II & 76,5 & $40 \%$ & $60 \%$ \\
Siklus III & 81,7 & $20 \%$ & $80 \%$ \\
\hline
\end{tabular}

Bersadarkan tabel di atas menunjukan bahwa adanya peningkatan hasil kemampuan menulis karya ilmiah mahasiswa di setiap siklus. Pada pra tindakan mahasiswa yang mencapai nilai minimal atau yang tuntas sebanyak $20 \%$ dan $80 \%$ mahasiswa tidak tuntas atau tidak mencapai nilai minimal yang dosen terapkan dan nilai rata-rata 58,5. Pada siklus I terdapat 30\% mahasiswa yang mencapai nilai minimal atau yang tuntas sedangkan masih terdapat $70 \%$ mahasiswa tidak tuntas atau tidak mencapai nilai minimal dan nilai ratarata 63,5 . Sedangkan pada siklus II mengalami peningkatan, terdapat $60 \%$ mahasiswa yang mencapai nilai minimal atau yang tuntas sedangkan masih terdapat $40 \%$ mahasiswa tidak tuntas atau tidak mencapai nilai minimal dan nilai rata-rata 76,5. Dan pada siklus ke tiga terdapat peningkatan sehingga kriteria keberhasilan terpenuhi. Terdapat $80 \%$ mahasiswa yang mencapai nilai minimal atau yang tuntas sedangkan masih terdapat $20 \%$ mahasiswa tidak tuntas atau tidak mencapai nilai minimal dan nilai rata-rata 81.7.

Berdasarkan hasil penelitian di atas, menunjukan rata-rata nilai keterampilan mahasiswa dalam menulis karya ilmiah menunjukan adanya kenaikan pada setiap siklusnya. Hal tersebut dapat dilihat dari kenaikan nilai rata-rata pra tindakan yaitu 58,5 dengan presentase 
ketuntasan sebesar 20\%, Rendahnya nilai pra tindakan karena mahasiswa masih mengandalkan salin tempel (copy paste) dari internet tanpa memikirkan dan melakukan riset terlebih dahulu tentang tema yang sudah dipilih serta mengabaikan sistematika penulisan yang sudah diberikan oleh dosen.

Sedangkan nilai rata-rata pada siklus I yaitu 63,5 dengan presentae ketuntasan sebesar $30 \%$. Nilai dan presentasi ketuntasan antara pra tindakan dan siklus I mengalami kenaikan, walaupun kriteria keberhasilan mengalami kenaikan $10 \%$ tetapi itu masih di bawah standar yang diharapkan. Kenaikan terjadi karena mulainya penerapan Group Investigation Model. Mahasiswa memiliki kesempatan untuk berdiskusi dengan kelompok dan mencari berbagai sumber untuk dituliskan dalam karya ilmiah.

Selanjutnya, nilai rata-rata siklus I dan siklus II pun terjadi peningkatan. Hal tersebut dapat dilihat dari nilai ratarata pada siklus II yaitu 76,5 dengan ketuntasan nilai keterampilan menulis karya ilmiah sebesar $60 \%$.

Pada siklus II terjadi peningkatan ketuntasan keberhasilan $30 \%$ hal ini terjadi karena grup atau kelompok mulai solid. The Group Investigation Model also trains character, discipline, is responsible in a team and finally forms an independent spirit (Nartini dan Darmadi, 2019: 41). Pada tahap berdiskusi kelompok, mahasiswa mulai menunjukan sikap disiplin dan tanggung jawab akan terselesaikannya tulisan mereka. Para mahasiswa mulai mencari berbagai macam sumber untuk menyelesaikan karya ilmiah dan mulai menumbuhkan karakter anti plagiatisme, yakni tidak sembarangan salin tempel (copy paste) dari google.
Lalu peningkatan dari siklus II dan siklus III adalah peningkatan yang membuat kriteria keberhasilan terpenuhi. Nilai rata-rata pada siklus III adalah 81,7 dengan ketuntasan nilai keterampilan menulis karya ilmiah sebesar $80 \%$.

Ketuntasan keberhasilan dapat terjadi di siklus III karena mahasiswa sudah mampu bekerja secara berkelompok dan dapat memanfaatkan kerja secara berkelompok dengan maksimal. Evaluasi yang diberikan oleh dosen menjadi acuan mahasiswa untuk memperbaiki karya ilmiah yang sudah dibuat. Dengan adanya kerja sama yang baik antar mahasiswa akan membatu proses belajar lebih baik karena mereka saling memberikan apa yang mereka ketahui. Karena mereka saling membantu untuk tercapainya tujuan yang yang ingin dicapai yaitu kesuksesan belajar bersama jadi mahasiswa yang mempunyai kemampuan yang berbeda saling melengkapi (Widiasari dan Sumantri, 2020: 149).

Secara umum dapat disimpulkan, bahwa dalam meningkatan keterampilan menulis karya ilmiah mahasiswa Semester I, Prodi PGSD, STKIP Kusuma Negara dapat menggunakan Model pembelajaran Kooperatif Tipe Group Investigation.

Berpijak pada pendapat Pratama dan Kartikawati (2017: 169) referring to the analysis of the needs that the learning outcomes are low, then the appropriate $\mathrm{Gl}$ method is applied to improve the ability to think analytically, critically, creatively, and productively so as to obtain maximum learning outcomes.

Berdasar pada analisis kebutuhan akan rendahnya nilai menulis karya ilmiah mahasiswa maka perlunya upaya peningkatan dengan 
menerapkan metode pembelajaran yang tepat, yakni menggunakan model pembelajaran kooperatif tipe group investigation. Dengan bekerja secara berkelompok dapat membuat mahasiswa menjadi lebih kritis dalam proses pembelajaran, yakni menyusun karya tulis ilmiah. Berdiskusi dalam kelompok untuk menentukan dan memecahkan masalah-masalah dalam proses pengerjaan karya tulis ilmiah. Mahasiswa dituntut untuk berperan aktif dalam proses pengerjaan karya tulis ilmiah dan tidak berpangku tangan dengan anggota kelompok lainnya.

\section{Tabel 2.}

Langkah-langkah Model Pembelajaran kooperatif Tipe Group Investigation Tahap

1. Pembagian kelompok Mahasiswa dibagi 10 kelompok $(1$ kelompok dan menentukan topik terdiri dari 3 mahasiswa) dan setiap kelompok akan diundi untuk penentuan tema yang akan dibuatkan karya tulis ilmiah

2. Mendiskusikan topik dan mencari sumber referensi

Setelah dibagi menjadi kelompok-kelompok kecil selanjutnya kelompok mendiskusikan topic yang didapatkan dan mulai menyusun kerangka karya tulis ilmiah dan mencari berbagai sumber referensi untuk mendukung karya tulis ilmiah yang dibuat.

3. Penulisan karya ilmiah Tahap penulisan karya ilmiah merupakan proses mahasiswa agar terhindar dari plagiatisme

4. Analisis dan sintesis

5. Presentasi final

6. Evaluasi
Dari tulisan yang sudah dibuat mahasiswa harus melakukan analisis dan sintesis terkait karya tulis yang sudah dibuat

Hasil karya tulis ilmiah yang sudah dibuat dipresentasikan sebagai bentuk tanggung jawab atas tulisan yang sudah dibuat dan sebagai sarana untuk memperluas wawasan mahasiswa karena aka nada sesi Tanya jawab dan diskusi dengan kelompok lainnya.

Dosen memberikan evaluasi akhir terhadap hasil tulisan mahasiswa. Aspek yang dievaluasi adalah sebagai berikut: sistematika penulisan, kebahasan (PUEBI, diksi, dan kalimat efektif), dan notasi penulisan ilmiah. 
Penerapan Model Pembelajaran tipe Group Investigation yang peneliti terapkan kepada mahasiswa dilakukan dengan menekankan mahasiswa agar melakukan peninjauan dengan tujuan memperoleh jawaban atas topik yang telah dipilih. Kecenderungan mahasiswa dalam mengerjakan tugas khususnya membuat karya ilmiah adalah mengambil jalan pintas (copy paste dari google).

Dengan berkelompok membuat mahasiswa harus berdiskusi tentang topik yang dipilih. Berdiskusi dengan kelompok serta mencari sumber reverensi yang akurat maka membuat jiwa anti plagiatisme dan tanggung jawab pada diri mahasiswa akan terpupuk. Setelah itu kelompok melakukan perencanaan (mencari sumber referensi yang akan digunakan), penerapan (menuliskan pemikiran hasil diskusi), analisis dan sintesis (mendeskripsikan dan menjelaskan segala persoalan yang ada), dan presentasi akhir (penyajian karya ilmiah), serta terakhir adalah evaluasi dari dosen dan kelompok. Ini dimaksudkan setiap kelompok mengetahui kelebihan dan kekurangan dari karya ilmiah yang sudah dibuatnya agar menjadi perbaikan kedepannya.

Model Pembelajaran tipe Group Investigation memiliki kelebihan dibanding dengan strategi belajar lainnya. Kelebihan tersebut adalah mahasiswa menjadi lebih aktif dan mampu menyumbangkan ide-ide yang ada di pikiran mereka, proses diskusi yang dilakukan mahasiswa dalam Group Investigation dapat meningkatkan keterampilan berbicara mahasiswa, mahasiswa mampu bekerjasama dalam tim dan meningkatkan pergaulan interaksinya, mahasiswa dapat terdorong secara aktif dalam kelompok dan menumbuhkan jiwa kritis, dengan grup investigasi memungkinkan dosen untuk memberikan pencingan pemahaman kepada mahasiswa untuk dicari solusinya, serta grup investigasi dapat meningkatkan kinerja dan pencapaian belajar mahasiswa, khususnya dalam penelitian ini adalah keterampilan menulis karya ilmiah.

\section{SIMPULAN}

Berdasarkan hasil penelitian yang telah dijelaskan, maka dapat disimpulkan bahwa Model Pembelajaran tipe Group Investigation dapat meningkatkan keterampilan menulis karya ilmiah mahasiswa Semester I Program Studi Pendidikan Guru Sekolah Dasar (PGSD), STKIP Kusuma Negara. Dengan data sebagai berikut: Hasil penelitian pra tindakan adalah rata-rata nilai mahasiswa adalah 58,5 dengan keberhasil ketuntasan sebesar $20 \%$. Siklus I ratarata nilai mahasiswa adalah 63,5 dengan keberhasil ketuntasan sebesar $30 \%$. Di siklus II rata-rata nilai mahasiswa adalah 76,5 dengan keberhasil ketuntasan sebesar $60 \%$.
Serta siklus III rata-rata nilai mahasiswa adalah 81,7 dengan keberhasil ketuntasan sebesar $80 \%$.

Peningkatan keterampilan menulis karya ilmiah mahasiswa dipengaruhi oleh aktivitas mahasiswa dan dosen dalam proses pembelajaran di kelas. Model Pembelajaran tipe Group Investigation memiliki dampak positif pada mahasiswa terhadap antusiasme untuk menulis karya ilmiah dengan menekankan karakter bertanggung jawab atas apa yang ditulisnya. Karena untuk membuat sebuah tulisan khususnya karya ilmiah mahasiswa haruslah memiliki jiwa nonplagiatisme. 


\section{DAFTAR PUSTAKA}

Afianti, N.W., Sulastry, T., Alimin. (2017). Penerapan Model Pembelajaran Kooperatif Tipe Kancing Gemerincing untuk Meningkatkan Keaktifan dan Hasil Belajar Peserta Didik Kelas $X$ MIA 3 SMAN 1 Bontomarannu. Jurnal Nalar Pendidikan, 5 (2): 544.

(https://ojs.unm.ac.id/nalar/article /view/4869 diakses 01 September 2020).

Amelia, F. dan Eva M. G. (2014). Pengaruh Model Pembelajaran Kooperatif Teknik Kancing Gemercing Terhadap Hasil Belajar Siswa Pada Materi Pokok Zat dan Wujudnya. (Online), 2(4):19-23,

(http://digilid.unimed.ac.id diakses 01 September 2020).

Chaer, Abdul. (2015). Psikolinguistik: Kajian Teoretik. Jakarta: Rineka Cipta.

Dardjowidjojo, Soenjono. (2018). Psikolinguistik: Pengantar Pemahaman Bahasa Manusia. Jakarta: Yayasan Pustaka Obor Indonesia.

Mukhtar. (2013). Metode Praktis Penelitian Deskriptif Kualitatif. : Referensi.

Nartini and Darmadi. (2020). Improving Student Mathematics Learning Achievement Through Group Investigation Learning Models. Social Sciences, Humanities and Education Journal (SHE Journal). Volume 1 (2) 35 - 42. 2020. ISSN: 2720-9946 (Online) The article is published with Open Access at: http://ejournal.unipma.ac.id/index.php/S HE (diakses 21 Oktober 2020).

Pratama, Hendrik dan Sulistyaning Kartikawati. (2017). The Effect of
WhatsApp Messenger As Mobile Learning Integrated with Group Investigation Method of Learning Achievement. International Journal of Science and Applied Science: Conference. Vol. 2 No. 1 Tahun 2017 Halaman 164-173. https://jurnal.uns.ac.id/ijsascs/arti cle/view/16702 (diakses 21 Oktober 2020).

Rusman. (2012). Model-model Pembelajaran Mengembangkan Profesionalisme Gru. : PT Raja Gravindo.

Sangadji,

Sopiah. (2016). Implementation of Cooperative Learning with Group Investigation Model to Improve Learning Achievement of Vocational School Students in Indonesia. International Journal of Learning \& Development, 6(1), 91-103.

(https://www.semanticscholar.org /paper/Implementation-ofcooperative-learning-With-groupSangadji/8918df28780db25748d afb89845a9e4ed8a57d25) (diakses pada tanggal 24 September 2020)

Suprapti, Yuyun Astuti and Putro, Khamim Zarkasih and Hamid, Mudasetia (2019) Peningkatan Keterampilan Menulis Teks Eksposisi Pelajaran Bahasa Indonesia Melalui Model Investigasi Kelompok Pada Siswa Kelas X Mipa 6 Sma Negeri 1 Temanggung Tahun Pelajaran 2018/2019. Halaman 22. Tesis, STIE Widya Wiwaha. http://eprint.stieww.ac.id/868/

(diakses pada tanggal 24 September 2020)

Tampubolon, Saur. (2014). Penelitian Tindakan Kelas. : Erlangga. 
Tarigan, Henry Guntur. (2008). Menulis: Sebagai Suatu Ketrampilan Berbahasa. Bandung: Angkasa.

Undang-Undang Nomor 12 Tahun 2002 pasal 35 ayat 3 tentang Perguruan Tinggi.

Undang-Undang Nomor 20 Tahun 2003 pasal 25 ayat 1 tentang Sistem Pendidikan Nasional.

Widiasari, Ni Kadek Rina dan Made Sumantri. (2020). Kooperatif Tipe Group Investigation Melalui Setting Lesson Study Terhadap Kompetensi Pengetahuan IPA. Jurnal Ilmiah Sekolah Dasar Volume 4, Number 2, 2020 p. 143-152.

https://ejournal.undiksha.ac.id/in dex.php/JISD/article/view/25094/ 15421 (diakses 21 Oktober 2020) 